\title{
INTERNATIONAL LAW AND INTERNATIONAL RELATIONS
}

\author{
DOI: 10.46340/eppd.2020.7.4.1
}

\author{
Amiran Khevtsuriani, Doctor of International Relations \\ ORCID ID: https://orcid.org/0000-0002-7739-7232 \\ Lili Kharchilava \\ ORCID ID: https://orcid.org/0000-0002-6461-4656 \\ Georgian Technical University, Georgia \\ CONCEPTUAL FOUNDATIONS \\ OF TURKISH FOREIGN POLICY \\ AT THE MODERN STAGE (PART 1)
}

The problem of the harmonious relationship between ideology and politics can be considered as one of the major challenges of modern world politics. For its part, the ideological side of foreign policy remains a complexly difficult direction. Also, one of the most difficult trends in modern international relations is globalization, which contributes to the development of some other trends. These include changing the notion of sovereignty, mostly trans nationalization issues that are primarily considered as national, and so on.

In the twentieth century, the idea of reducing the role of religion in social processes is dominating, it was associated with the revival of theories of modernization and secularization, its starting point was the end of the religious confrontation. At the same time, one can not fail to mention the fact that Islam is a relatively young religion and in the second half of the twentieth century, it went through all the stages that were previously significant for the Christian religion in past.

Keywords: Turkey, US Iran, Russia, The European Union, Middle East, Ideology, Atheism, Referendum, Islam, Constitution.

After the end of the bipolar confrontation era, a hypothesis about the end of ideological competition emerged in the West. According to Francis Fukuyama, liberal values have won this competition, which has finally put an end to the era of ideological controversy ${ }^{1}$.

But as we know, ideologies have existed for centuries and the 21 st century could not have been an exception ${ }^{2}$. New types of micro and macro ideologies have emerged in the world political arena, which, at least regionally, if not globally, form the political agenda. A prominent example of this is the relatively severe (Iran) and light (Turkey) forms of Islam.

The problem of the harmonious relationship between ideology and politics can be considered as one of the major challenges of modern world politics. For its part, the ideological side of foreign policy remains a complexly difficult direction. Also, one of the most difficult trends in modern international relations is globalization, which contributes to the development of some other trends. These include changing the notion of sovereignty, mostly trans nationalization issues that are primarily considered as national, and so on.

In the twentieth century, the idea of reducing the role of religion in social processes is dominating, it was associated with the revival of theories of modernization and secularization, its starting point was the end of the religious confrontation. At the same time, one can not fail to mention the fact that Islam is a relatively young religion and in the second half of the twentieth century, it went through all the stages that were previously significant for the Christian religion in past. In this context, it is necessary to highlight the role of Islam in anti-colonial movements and then in regional conflicts. These activities resulted in the establishment of the Organization of the Islamic Conference, which was later transformed into the "Organization of Islamic Cooperation".

\footnotetext{
${ }^{1}$ Fukuyama, F. (1992). The end of history and the last man. New York, 418.

${ }^{2}$ Сирота, Н.М. (2011). Идеология и политика. Москва: Аспект пресс.
} 
In Islamic countries, the process of searching for their model of development continues at the modern stage, which will be based on the principles of Islam and combine modern achievements and trends of development. An integral part of these processes can be considered the cardinal transformation of the foreign-political ideology of the Republic of Turkey since 2002, which is connected with the coming to power of the "Justice and Development Party". From this period, there was a gradual distancing from the fundamental principles of the "Kemalist policy" characteristic of the Turkish Republic, which was replaced by a policy saturated with moderately Islamic ideology, which includes elements of "Pan-Turkism" and "Pan-Islamism".

"The Justice and Development Party" is diversifying its foreign policy, activates the Eastern vector of foreign policy following the cooperation with the West, and develops relations with Russia, China, the Arab and African countries. In the framework of bilateral cooperation, after economic interests, the Turkish leadership, which is the initiator of the modern ideology of the country's foreign policy, is often driven by hidden political goals, the signs of which are often visible.

For almost eighty years since the establishment of the Republic of Turkey, its main political ideology in both domestic and foreign policy has been "Kemalism", founded by the first President of Turkey, Mustafa Kemal Ataturk. It is true that, according to the Constitution, Kemalism still maintains its position, but in reality, its role is significantly weakened at the present stage, which has repeatedly been the subject of acute criticism within the country.

"Kemalism", as a national ideology, dates back to the establishment of the Republic of Turkey when Mustafa Kemal Ataturk, the most popular general and political figure in the country, came to power. He took over the governance of the country at the most difficult historical stage for Turkey. This is a period of fighting against the "Triple Entente" countries, which have openly threatened the country's sovereignty and territorial integrity.

Ataturk laid the foundation for a new ideology of the country's domestic and foreign policy, which for many years determined Turkey's political agenda. The following six principles were considered the fundamental basis for the development of the country, which was strengthened by the force of the Constitution: republicanism, nationalism, citizenship, laicism (secularism), statism, and devotion to revolutionary principles.

Republicanism included the complete liquidation of the monarchy and the creation of a democratic parliamentary republic. As well as the selectivity of the governing system and its accountability to the people.

The principle of nationalism is seen in the worldview of Kemalism as a counterbalance to PanTurkism within the new borders of Turkey, without reference to the national component. Turkish "nationalism" is the cornerstone of Turkish state ideology, reinforced by the power of the constitution. Turkish nationalism, on the other hand, is largely different from the classical understanding. The ruling elite saw this principle as the basis for the inseparability of nation and state, (devlet ve millet bölünmez bir bütündür), as the main basis of Political Unitarism. In other words, this principle involved the integration of all national ethnic groups within a single Turkish nation. By the way, such wording is also given in the constitution: "All Turkish citizens are Turks"1.

The principle of "statism" meant the formation of a mixed economy, with a special role for the state. This conceptual approach has led to the nationalization of most enterprises and the emergence of large stateowned holdings.

"Laicism", the same as secularization, meant the separation of Islam from the state. Ataturk carried out several courageous reforms, including the abolition of Sharia law, the suspension of religious education, the transfer of most educational institutions to the subordination of the Ministry of Education, and so on ${ }^{2}$.

It should be noted that until recently, in Turkey, all parties whose political activities were based on the ideas of Islam were severely persecuted by law enforcement agencies. Particularly noteworthy are the country's armed forces, which have been seen as key defendants of the principles of "laicism." It can be said that until 2014, in the formation of Turkey's political agenda both within the country and the international arena, along with the President, the Prime Minister, and the Parliament, the military forces of the country played an important, in some cases crucial, role.

Turkey's foreign policy ideology has changed fundamentally since the "Justice and Development Party" came to power. The principles and visions established by Ataturk are a thing of the past now. "Statism"

\footnotetext{
${ }^{1}$ Anayasası, T.C. (2008). Seçkin yayınevi. Ankara.

2 По данным официального сайта Министерства туризма и культуры Турецкой Республики.

$<$ http://www.kultur.gov.tr $>$.
} 
was eliminated, and the principle of "republicanism" in its Kemalist sense was no longer the main ideological pillar of the country. It was during this period that the idea of moving from a model of a parliamentary republic to a model of presidential one became increasingly popular, which eventually led to even more logical consequences. Today, Turkey is a sharply presidential republic.

In recent years, Turkey has been trying to present its foreign policy as a multi-vector, independent, and oriented on national interests of the country ${ }^{1}$. In foreign policy, the main ideological doctrine became the concept of former Prime Minister Ahmed Davidoglu - "Zero Problems in Neighborhood Relations."

The geographical location of the Turkish state is very important in terms of geopolitics. It has the greatest potential to expand its spheres of influence, primarily due to its historical heritage and religious and ethnic affiliation. There are three unofficial concepts in the Turkish political worldview: Turan, Ergenekon, and New Ottomanism.

Ergenekon - is the mythical homeland of the Turkish people. According to modern Turkish scholars, this area included the lands around Lake Baikal. Turan - means the settlement area of the people of the Turkish origin, starting from Lake Baikal, including the state borders of modern Turkey. And, the new Ottomanism as a political concept, implies the restoration of the Ottoman Empire within its historical borders.

The ruling "Justice and Development Party" has launched a series of reforms since coming to power. Among them is the range of economic, military, and political reforms. The somehow clever and at the same time insidious policies of the ruling leaders have weakened the previously dominant positions of the army in the country's political processes. A referendum, conducted in 2010 also transformed the country's main law. It allowed the government to increase its influence on the political process in the country. At the same time, the main foreign policy doctrine of the country - "zero problems in relations with neighbors" continued, which eventually led to the diversification of foreign policy ${ }^{2}$.

At the same time, it is noteworthy that the economic reforms carried out by the ruling party have contributed to the inflow of Arab capital into the country and the strengthening of the positions of party subjects. In other words, from an economic and political point of view, the ruling team has pursued a completely sensible policy based on its party interests. In particular, it has formed its lobby in all sectors, thus gaining maximum influence in all key segments.

Today, Turkish political and public life is dominated by the idea of forming close economic and political ties with its neighbors, deepening relations with the Arab world, the Eastern countries, and Russia. Political leaders with a moderately Islamic worldview, while limiting the political role of the military in the country, have allowed themselves to pursue largely independent policies even within the "NATO" bloc.

It is no news to anyone that there is no harmonious relationship between Turkey and the West nowadays. Indeed, it has always stood far from ideal, though, lately it has been considerably colder. First of all, Turkey has practically lost its enthusiasm for European integration, which was primarily due to differences of opinion with key EU players - Germany and France. Besides, Turkey's independent military action in the Syrian conflict and its involvement in the north damaged this relationship. Of course, the West, and especially the United States, could not leave without paying attention to President Erdogan's increasingly frequent relations with Russian President Vladimir Putin and the leader of the Islamic Republic of Iran.

Relations with Europe remain one of the most painful issues in Turkey's foreign policy. European countries and institutions strongly criticize Ankara on issues such as human rights, democracy, freedom of media, and minority rights. Due to this, at this stage, the process of negotiations on Turkey's accession to the European Union, which had begun years ago, is practically frozen. The Cyprus problem remains unresolved. In response, Ankara accuses Europe of bias and tendentiousness, saying that people express their views on elections and referendums, which is a sign of democracy. As for the ongoing political repression inside the country, Ankara explains that their implementation has become necessary due to the country's security needs.

The position of most European countries on the recognition of the 1915 "Armenian Genocide" is especially irritating for Turkey, which is categorically opposed by official Ankara. Many Western states have acknowledged the fact of the Armenian Genocide in the Ottoman Empire in the early twentieth century, which, according to unconfirmed data, sacrificed 1.5 million ethnic Armenians. The Armenian Genocide has been officially recognized and tried by France, Germany, Italy, Belgium, Sweden, Lithuania, Greece, Cyprus, the Netherlands, Switzerland, Poland, Slovakia, Russia, Switzerland, Canada, Venezuela, the Vatican,

\footnotetext{
${ }^{1}$ Надеин-Раевский, В.А. (2013). Внешняя политика Турции: ветры перемен. Мировая экономика и международные отношения, 2, 84-92.

${ }^{2}$ Q\&A: Turkey's constitutional referendum. BBC News. <www.bbc.com>news >world-europe-11228955>.
} 
and others. Denial of the historical fact of the Armenian Genocide is punishable in some EU countries and carries a fine of 45,000 euros and imprisonment for up to 1 year. The fact of genocide is officially recognized in 40 out of 50 US states. April 24 has also been declared as a day of remembrance for the victims of genocide ${ }^{1}$.

Of course, this fact is, from a reputational point of view, the heaviest blow to the international image of Turkey as the successor state of the Ottoman Empire.

There are also problems in Turkish-American relations, which are mostly related to the Syrian crisis. Ankara is concerned about US support for Kurdish rebels and has so far demanded in vain the extradition of Imam Fethullah Gulen, who is accused of organizing a 2016 military coup and terrorism and lives in the US state of Pennsylvania. Relations between the two countries have been intensified by differences over the Palestinian issue and the 2010 Gaza Flotilla incident.

Turkey seeks to normalize relations with Iran. It also has differing views from the United States on Iran's nuclear program. The volume of trade turnover between these two countries is also increasing. As for other neighbors, Turkish-Russian cooperation is growing steadily, including from a strategic point of view.

Despite differences of opinion on many key issues, Turkey's role in regional security is so important that no one in the West has yet questioned its NATO membership.

Today, Turkey's ruling party is stronger than ever. President Recep Tayyip Erdogan, who has been the head of the country for more than 17 years, enjoys enormous rights and is de facto the sole ruler of the country. It can be said that after Ataturk he is probably the most charismatic leader in the history of modern Turkey. Erdogan has often been the subject of criticism from Western media for his sensational remarks, which often contain pan-Turkish and pan-Islamic nature.

April 16, 2017, can be considered as a turning point in the history of modern Turkey. According to the results of the referendum held on this day, substantial changes have been made in 18 Article of the Constitution of the country. $51.4 \%$ of Turkish voters supported the package of constitutional amendments, which provided for increased rights in the presidency of the country, including the abolition of the post of Prime Minister. The changes were met with a backlash from the country's opposition ${ }^{2}$.

According to Turkish officials, the changes were necessary to address the security problems and challenges facing the country. Recently, Ankara has really had to fight on several fronts at once.

The historic referendum was preceded by a failed coup d'etat that caused a great deal of controversy both inside and outside the country.

\section{References:}

1. Vjekjerelu, M. (2011). Turcija: politicheskie perspektivy [Turkey: political perspectives]. Geopolitika [Geopolitics], iss. IX. Moscow, MGU. [in Russian].

2. Isaev, G.G., Sotnichenko, A.A. (ed.) (2010). Blizhnij Vostok: vojna i politika [Middle East: War and Politics]. Moscow: IDM. [in Russian].

3. Keduri, Je. (2010). Nacionalizm [Nationalism]. Saint Petersburg: Aletejja. [in Russian].

4. Nadein-Raevskij, V.A. (2013). Vneshnjaja politika Turcii: vetry peremen [Turkish Foreign Policy: Winds of Change]. Mirovaja jekonomika i mezhdunarodnye otnoshenija [World economy and international relations], no. 2, 84-92. [in Russian].

5. Türkiye Cumhuriyeti Turizm ve Kültür Bakanliğl [The Ministry of Tourism and Culture of the Republic of Turkey]. <http://www.kultur.gov.tr>. [in Turkish].

6. Sirota. N.M. (2011). Ideologija i politika [Ideology and politics]. Moscow: Aspekt press. [in Russian].

7. Anayasası, T.C. (2008). Seçkin yayınevi [Distinguished publishing house]. Ankara. [in Turkish].

8. Armenian Genocide. The Young Turks, Causes \& Facts. <www.history.com〉topics〉world-war-i $>$ armenian-ge>. [in English].

9. Fukuyama, F. (1992). The end of history and the last man. New York. [in English].

10. Q\&A: Turkey's constitutional referendum. BBC News. <www.bbc.com>news>world-europe-11228955>. [in English].

11. Turkish referendum: all you need to know (2017). World news. <www.theguardian.com>world>2017>apr>turkish-r>. [in English].

\footnotetext{
${ }^{1}$ Armenian Genocide. The Young Turks, Causes \& Facts. <www.history.com $>$ topics $>$ world-war-i>armenian-ge>.

${ }^{2}$ Turkish referendum: all you need to know (2017). World news. $<$ www.theguardian.com>world $>2017>$ apr $>$ turkish-r $>$.
} 